\begin{tabular}{lc}
\hline & ANNALES \\
& UNIVERSITATIS MARIAE CURIE-SKŁODOWSKA \\
LOL. V & SECTIO N \\
\hline
\end{tabular}

ISSN: 2451-0491 • e-ISSN: 2543-9340 - CC-BY 4.0 • DOI: 10.17951/en.2020.5.225-237

\title{
Mnemosyne w muzeum i w szkole
}

\section{Mnemosyne in Museum and at School}

\author{
Marta Rusek \\ Uniwersytet Jagielloński. Wydział Polonistyki \\ ul. Gołębia 16, 30-007 Kraków \\ marta.rusek@uj.edu.pl \\ https://orcid.org/0000-0002-5794-9925
}

\begin{abstract}
The article is dedicated to the issue of cultural memory in Polish studies. It is discussed in the context of the so-called memory turn, and the transformations occurring in the museum science under the influence of the "new museology". The text consists of three parts. The first one concerns the changes and shifts in the discourse of cultural and social memory in the days of the increasing musealization process. The second one indicates new educational strategies in narrative, critical, and especially in participatory museums, which contributes to the formation of new models of participation in culture and of receptive habits. The third part, on the other hand, provides diagnoses concerning challenges, as well as the hints which the transformations of the museum activities in the field of education offer to Polish studies.
\end{abstract}

Keywords: cultural memory; memory turn; Polish studies; new museology; participatory museum

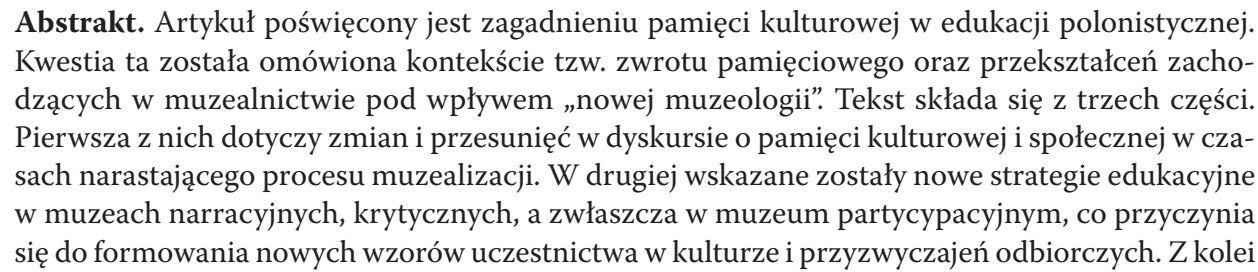


trzecia część przynosi rozpoznania dotyczące wyzwań, ale i podpowiedzi, jakie dla kształcenia polonistycznego płyną z transformacji zachodzących w działalności muzeów na polu edukacyjnym.

Słowa kluczowe: pamięć kulturowa; zwrot pamięciowy; edukacja polonistyczna; nowa muzeologia; muzeum partycypacyjne

\section{PAMIĘĆ I MODI MEMORANDI}

Mnemosyne przyzywam, Zeusa małżonkę, władczynię,

Która zrodziła Muzy, najświętsze o głosach przeczystych,

$\mathrm{Z}$ dala będące od zapomnienia, co rozum otępia

zawsze, dzierżąca myśl każdą w duszach śmiertelnych żyjącą,

która powiększa i wzmacnia potęgę rozumu człowieka [...].

(Żybert 2012: 103, cyt. za: Bartol 2016: 21) ${ }^{1}$

Przywołuję ten pełen pasji i uwielbienia orficki hymn anonimowego twórcy z pierwszych wieków naszej ery, ponieważ kult Mnemosyne - dawczyni życia świadomego i rozumnego - starożytni Grecy przekazali w spadku kolejnym wiekom. Matka Muz, oblubienica Zeusa, zrodzona ze związku Gai i Uranosa, czyli dwóch pierwotnych żywiołów: ziemi i nieba, miała boskie pochodzenie i należała do pokolenia tytanów. Ten rodowód sprawiał, że - co podkreśla znawczyni tematu Krystyna Bartol (2016: 13), do której ustaleń się tutaj odwołuję - bogini ta nie była uważana za personifikację emocji człowieka, nie była też jedynie alegorycznym konceptem przedstawiającym zdolności ludzkiego rozumu. Przypisywano jej inną rolę. Według starożytnych wierzeń Mnēmosynē Pamięć stanowiła źródło wiedzy uniwersalnej, wykraczającej poza doświadczenie jednostki, i właśnie tę wiedzę przekazywali w swych opowieściach aojdowie (tamże: 12-13), wydobywając człowieka z jego teraźniejszości, z zanurzenia $\mathrm{w}$ hic et nunc. Tematy i motywy utrwalane $\mathrm{w}$ ich pieśniach, a potem $\mathrm{w}$ tekstach pisanych, tworzyły pamięć zbiorową. Boska, ponadindywidualna Mnēmosynē - Pamięć była zatem związana z pamięcią społeczną, zakorzenioną w historii, a jej uzupełnienie, ale też przeciwieństwo, stanowiła jednostkowa, ograniczona mnèmosynē - wspomnienie.

1 Nieco inne tłumaczenie tego hymnu zaproponowała Joanna Rybowska (2011: 28): „Wzywam Mnemosyne, Oblubienicę Zeusa, Władczynię, / Matkę świętych, bogobojnych, o słodkim głosie Muz. / Tę, która jest przeciwieństwem złego zapomnienia / odbierającego nam rozum na zawsze. / Mnemosyne, która spaja wszystkich myśli, / współzamieszkujące dusze śmiertelnych, / i wzmacnia potężne zdolności człowieka do myślenia”. 
Z dzisiejszego punktu widzenia ważny jest nie tylko ten uniwersalny charakter pamięci, lecz także to, co ukazują w związku z Mnemosyne alegorie zamieszczone w Ikonologii Cesarego Ripy. Zatrzymam się na chwilę przy tych szesnastowiecznych przedstawieniach, bo wydają się symptomatyczne. Pamięć wyobrażona jest w nich jako ubrana w czarną szatę kobieta w średnim wieku, która jedną ręką przytrzymuje czarnego psa, a drugą dotyka ucha. Wszystko tu znaczy. Czerń nie symbolizuje żałoby, tylko stałość i niezmienność, wiek - czas największej sprawności intelektualnej, pies - zgodnie z wierzeniami jest zwierzęciem o znakomitej pamięci, a ucho miało stanowić jej siedzibę. Najważniejsze jest jednak przybranie głowy, czyli puzderko pełne klejnotów, które świadczy - oddajmy głos Ripie (2012: 308) - o tym, że „pamięć nadzwyczaj wiernie zatrzymuje i przechowuje wszelkie rzeczy podsuwane jej przez zmysły i wyobraźnię, zwie się ją tedy arką wiedzy oraz Skarbów duchowych". Szczególnie sugestywnie brzmi przenośnia „arka wiedzy oraz skarbów duchowych”, można ją bowiem zgadzając się na pewne uproszczenie - tłumaczyć jako wartościowy, bezcenny spadek, a mniej metaforycznie jako dziedzictwo czy pakiet znaczeń istotnych. To pamięć bierna. Współczesna badaczka Aleida Assmann (2009: 128-135, 136-139) ten typ nazwała pamięcią magazynującą, przypominając tradycję mnemotechniczną, ale też koncepcję magazynu - skarbca pamięci z Wyznań św. Augustyna (Saryusz-Wolska 2014b: 341).

W Ikonologii znajduje się jeszcze jedno wyobrażenie pamięci - to kobieta o dwóch twarzach, znów w szatach koloru czarnego, która w prawej dłoni trzyma pióro, a w lewej książkę. W alegorezie Ripa (2012: 309) tak tłumaczy koncept dwóch twarzy: „[...] pamięć obejmuje wszystkie rzeczy przeszłe i porządkuje je według reguły Rozsądku z myślą o rzeczach, które mają nadejść". Z kolei pióro i książka symbolizują charakterystyczne dla ery nowożytnej media pamięci, które ją utrwalają i przenoszą. Transmisja przeszłości w przyszłość miała mieć zatem charakter celowy, podlegała racjonalnym zasadom.

Przypominam te antyczne źródła i nowożytne przedstawienia, gdyż na ich tle lepiej, bardziej przekonująco rysują się współczesne kłopoty z pamięcią. Zauważając je, nie myślę jednak o związanej z kształceniem mnemotechnicznej tradycji i jej zasadach, lecz łączę owe kłopoty z ważnymi dla edukacji pytaniami o funkcjonowanie pamięci - i tej społecznej, i tej indywidualnej, a także o ich wpływ zarówno na doświadczenie jednostek, jak i na istnienie zbiorowe. Pytania te w dyskursie naukowym postawił mocno wiek XX. Dzisiaj, za uczniem Émila Durkheima, socjologiem Mauricem Halbwachsem (2008)², twórcą określenia „pamięć zbiorowa”, mówimy o „ramach pamięci”, operujemy też kategorią

\footnotetext{
2 Książka po raz pierwszy została wydana w 1925 roku.
} 
„długiego trwania”, Derridiańską figurą śladu jako „obecnego znaku nieobecnego sensu", a za historykiem kultury i socjologiem Stefanem Czarnowskim (1956: 108-121) pytamy o „dawność w teraźniejszości”. Zagadnienie pamięci dyskutowane jest przez socjologów, antropologów, historyków, kulturoznawców czy literaturoznawców; w środowiskach naukowych toczą się spory o tzw. zwrot pamięciowy w humanistyce, ustanawiający nowy badawczy paradygmat.

Zainteresowanie pamięcią jest jednak o wiele rozleglejsze. Nie będę tutaj mnożyć przykładów, wystarczy, że wspomnę tzw. memory boom - zjawisko, którego początki sięgają lat 80. XX wieku. Wiąże się ono m.in. z mnogością dzieł literackich, filmowych, plastycznych, powstających też w nurcie sztuki popularnej, które podejmują i przepracowują temat przeszłości. O uprzywilejowaniu pamięci, a nawet - jak chcą niektórzy - obsesji na jej punkcie, świadczą również rozmaite praktyki upamiętniania, związane z tzw. politykami pamięci, czy narastający proces muzealizacji przeszłości (por. Korzeniewski 2006: 221-227; Saryusz-Wolska 2014: 224) ${ }^{3}$. Ważniejszy od zjawisk ilościowych jest jednak fakt, że pamięć znalazła się w centrum współczesnej refleksji. Zainteresowanie nią okazuje się tym bardziej spektakularne, że wydaje się kontrastować z charakterystycznym dla naszych czasów poczuciem niepewności i przygodności istnienia, choć w istocie je dopełnia. Nie sposób przy tym nie zauważyć, że dzisiejszy wzmożony namysł nad Mnemosyne - Pamięcią wynika z zauważania historycznej zmienności w jej rozumieniu. O tym jak podstawowe są to rozpoznania, świadczy tytuł fundamentalnej dla mnie publikacji Modi memorandi. Leksykon kultury pamięci. Zwracam na niego uwagę, ponieważ gramatyczna a zatem wydawałoby się drobna - zamiana, czyli zastosowanie liczby mnogiej w miejsce pojedynczej, owo modi memorandi, pokazuje pamięć jako zjawisko wieloaspektowe, niejednolite (por. Saryusz-Wolska i Traba red. 2014: 15-16). Autorzy idą tutaj drogą wyznaczoną przez Jana Assmanna (2015: 64-71), który pisał o pamięci kulturowej i komunikatywnej, oddzielonych od siebie floating gap - dryfującą luką. Z kolei użyte w rozwinięciu tytułu tego leksykonu pojęcie kultura pamięci ma charakter nadrzędny i obejmuje - co zaakcentowano we Wprowadzeniu - wszystkie możliwe formy świadomego zaświadczania o przeszłości (por. Saryusz-Wolska i Traba red. 2014: 16-20).

Wskazane powyżej zmiany w rozumieniu i ujmowaniu pamięci polegają - pozwolę sobie na uproszczenie - na odebraniu jej nie tylko nadanego przez

3 Autorka przypomina, że za twórcę terminu memory boom uważa się Andreasa Huyssena (1995).

4 Assmann (2015: 60) zauważa, że „[k]ultura pamięci wiąże się z »pamięcią stanowiącą wspólnotę«". 
Greków przymiotu boskości, rozumianej tutaj jako uniwersalność, powszechność, a zatem tak fundamentalnych cech, jak stałość i niezmienność, lecz przede wszystkim na ujawnieniu różnych ram, trybów i sposobów jej funkcjonowania. Pamięć - strażniczka tradycji - nie jest postrzegana jako zamknięty skarbiec, spadek, który się biernie przekazuje i biernie odtwarza, lecz jako dynamiczny proces, obejmujący tak zbiorowe, jak i indywidualne doświadczenie pamiętania. Taką właśnie pamięć - niejednoznaczną, nieoczywistą, nieprzejrzystą - ukazuje alegoria z cyklu Niezbyt wyraźnie stworzonego przez współczesną artystkę Kamę Sokolnicką (2012). Praca przedstawia kobietę w czarnym stroju, która zamiast głowy ma wielki diament. Inspiracją do jej powstania było zdjęcie pielęgniarki wydobyte z archiwum Muzeum Zamku i Szpitala Wojskowego na Ujazdowie. Rysunek to jakby negatyw tej fotografii. Odwróceniu uległy tutaj kolory - biały fartuch stał się czarny. Zmiana barw oraz zabieg swoistej depersonifikacji postaci sugerują, że pamięć ma charakter fantomowy, widmowy.

Dla prowadzonych tutaj rozważań ważne jest rozpoznanie, że przekształcenia w dyskursie o pamięci oddziałują na wyobraźnię zbiorową, mają również konsekwencje dla muzeum i szkoły. W ich świetle zasadne jawi się pytanie, czy w kształtowaniu pamięci kulturowej instytucje te odgrywają rolę jej wyzwolicieli czy też czynią młodych ludzi zakładnikami tego, co minęło.

\section{OD ŚWIĄTYNI DO FORUM - PODPOWIEDZI NOWEJ MUZEOLOGII}

Krytyka muzeum, w którym przeszłość nie znajduje sposobu swej artykulacji, a więc nie kształtuje pamięci, narasta już od początku XX wieku. W 1923 roku Paul Valéry napisał:

Nie bardzo lubię muzea. Wiele jest godnych podziwu, nie ma rozkosznych. [...] Przede mną roztacza się w ciszy osobliwy, zorganizowany bezwład. Chwyta mnie święte przerażenie. Krok mój staje się nabożny. [...] Wkrótce nie wiem już, po co przyszedłem do tych wywoskowanych samotni, które mają w sobie coś z świątyni i z salonu, z cmentarza i ze szkoły. (Valéry 1974: 146)

W subiektywnym odbiorze poety sakralny wymiar muzeum, ukryty również w nazwie, której etymologia sięga greckiego mouseionu, czyli siedziby-świątyni Muz, łączył się z edukacyjnym przymusem i pustką mauzoleum. Sprzeciw budził kolekcjonerski chaos zmieniający muzeum w archiwum czy w magazyn rzeczy, które nie tworzą pamięci żywej, a skłaniają jedynie do katalogowania. Ten podnoszony w nurcie nowej muzeologii paradoks „martwego trwania” przedmiotów 
z przeszłości doskonale oddaje Wisława Szymborska (1996: 16) w znanym wierszu Muzeum (tomik Sól ziemi z 1962 roku). Pamiętamy te frazy:

Są talerze, ale nie ma apetytu,

Są obrączki, ale nie ma wzajemności

Od co najmniej trzystu lat.

[...]

Z braku wieczności zgromadzono

Dziesięć tysięcy starych rzeczy.

Poetycki obraz w sugestywny sposób pokazuje, jak w kolekcjach muzealnych rzeczy zmieniają swój status. Pozbawione pierwotnego kontekstu, nie tylko nie pełnią przypisanych im funkcji, lecz także - umieszczone w innej ramie - stają się obiektami do oglądania, materialnymi reliktami, które nie dają wglądu w doświadczenie człowieka. W ten sposób muzeum staje się swoistym archiwum, a zarazem metaforą pamięci magazynującej.

W opozycji do takiego pojmowania muzeum zrodził się nurt „nowej muzeologii”. Twórca tej nazwy, Peter Vergo, podsumowując debaty z lat 70. i 80., podkreślał, że głównym celem działalności muzealnej jest kontakt z odbiorcą (por. Borusewicz 2012: 102-103). Ta zasadnicza zmiana w myśleniu o roli muzealnej instytucji wpłynęła nie tylko na przeniesienie akcentu ze zobowiązań wobec kolekcji na zobowiązania wobec społeczeństwa (Janus 2015: 13), którego dziedzictwo jest gromadzone, przechowywane i uprzystępniane, lecz także przyczyniła się do zdemaskowania uprzywilejowanej pozycji muzeum jako dostarczyciela wiedzy ponadindywidualnej.Jak podkreślają badacze, najważniejszym skutkiem było dowartościowanie relacji muzeum - zwiedzający oraz promowanie idei aktywnego muzeum, w którym odbiorca jest angażowany w procesy przedstawiania i interpretacji (tamże: 15). Skupienie na widzu pociągnęło za sobą nowe, inne modele zachowań edukacyjnych, które odwołują się do swobody wyboru i idei ciągłego samokształcenia, są mniej formalne, a bardziej nastawione na informację zwrotną, adresowane do ściśle określonych grup (tamże: 13-14; Karczewski 2015: 24-30; Radecki 2015: 6-22).

Wskazany w tytule tej części tekstu kierunek transformacji zachodzących w myśleniu o muzeum i w samej instytucji zaczerpnęłam ze znanego muzealnikom artykułu Duncana F. Camerona pt. Muzeum - światynia czy forum? z $1971 \mathrm{roku}^{5}$. To jedno z pierwszych świadectw kształtowania się nurtu „nowej

5 Artykuł Camerona był wielokrotnie cytowany i przedrukowywany (por. Irvine 2006; na temat muzeum jako forum zob. m.in. te Heesen 2016: 174-177). 
muzeologii", która zrodziła takie formy muzealniczej działalności, jak muzeum narracyjne (Kowal i Wolska-Pabian red. 2019), partycypacyjne i krytyczne (por. Piotrowski 2011), proponując nie tylko inny sposób uczestniczenia w kulturze, lecz także - co pragnę podkreślić - oddziałując na praktyki edukacyjne. W tym ujęciu dziedzictwo przeszłości nie jest pojmowane jako zamknięty przekaz, a jako spadek, który jest dany do roz-poznania, od-tworzenia, na rozumienie którego wpływa również teraźniejszość. Co więcej, obok poznania intelektualnego równie silnie akcentowana jest rola doświadczeń zmysłowych.

Najbardziej radykalną zmianę przynosi koncepcja muzeum partycypacyjnego - obojętnego widza zastępuje tutaj odbiorca, który włącza się w działania wystawiennicze. Nina Simon, propagatorka tej idei, przedstawia ją następująco:

Instytucja służy za „platformę” łączącą różnych użytkowników, którzy stają się aktywnymi twórcami treści, jej dystrybutorami, konsumentami, krytykami oraz współautorami. Oznacza to, że instytucja nie próbuje dostarczać zwiedzającym z góry określonego doświadczenia - zamiast tego daje zwiedzającym szansę aktywnego współtworzenia własnego doświadczenia. (Simon 2015: 23; por. Ziębińska-Witek 2014: 293-308)

Przykłady takich działań obserwujemy w wielu polskich muzeach, tutaj przywołam dwa. Pierwszy to wystawa sztuki polskiej przełomu XIX i XX wieku w Muzeum Pałac Herbsta w Łodzi pt. Jak to widzisz?, która powstała w wyniku długofalowej współpracy z odbiorcami ${ }^{6}$. Zapoczątkował ją plebiscyt na wybór czterdziestu ze stu obrazów, które miały być zaprezentowane na ekspozycji czasowej. Widzowie wskazywali pięć dzieł i uzasadniali swoje decyzje, a ich głosy wzięły udział w konkursie na najciekawiej uargumentowaną wypowiedź. $\mathrm{Ci}$, którzy wygrali, zostali zaproszeni do zespołu kuratorskiego i przez kilka miesięcy wraz z muzealnikami pracowali nad przygotowaniem wystawy. W tym wieloetapowym projekcie ważny był zarówno efekt końcowy, jak i cały proces powstawania ekspozycji, naruszały one bowiem tradycyjny układ. Muzeum zrezygnowało z funkcji jedynego depozytariusza wiedzy i dostarczyciela dominującej opowieści o sztuce, którą tworzy już poprzez sam dobór obiektów i ich układ, z kolei publiczność została wyrwana z roli biernego widza, a co ważniejsze, miała szansę odkrywać sam proces konstruowania muzealnej narracji i tym samym sposoby oddziaływania na pamięć zbiorową czy kulturową.

6 Z koncepcją tego projektu oraz z jego realizacją można zapoznać się dzięki materiałom dostępnym w internecie (zob. „Jak to widzisz?” - wystawa... 2018; Wystawa... 2018). 
Kolejny przypadek, który miałam okazję bezpośrednio obserwować, to działania zaprojektowane wokół wystawy Widok zza bliska. Inne obrazy Zagłady w Muzeum Etnograficznym w Krakowie (zob. Widok zza bliska... 2018). Wzięła w nich udział grupa studentów, którzy najpierw zobaczyli ekspozycję, a następnie w małych zespołach mieli stworzyć mini-wystawy z eksponatów przechowywanych w magazynach, stanowiących świadectwo stosunku ludności polskiej do żydowskiej. Aby zrealizować zadanie, musieli dokonać analizy opisów zamieszczonych na kartach inwentarzowych obiektów zdeponowanych w muzeum, co pomogło dostrzec emocje i postawy ujawniające się w teoretycznie neutralnym naukowym języku i przekazie. Cały eksperyment zwieńczony był warsztatami dotyczącymi afektów i emocji, jakie towarzyszyły studentom podczas całego procesu: od oglądania wystawy po przygotowanie i zaprezentowanie swych małych ekspozycji.

Oba projekty pozwoliły uczestnikom na rozpoznawanie języka muzeum, poziomów kształtowania się muzealnej narracji i jej wiarygodności oraz na konfrontowanie odmiennych punktów widzenia, a tym samym rozpoznawanie różnic w doświadczeniu odbioru i funkcjonowaniu zbiorowych wyobrażeń, co wiązało się także z odkrywaniem emocjonalnego stosunku do przekazów pamięci kulturowej. W obu przypadkach muzeum okazało się forum, a odbiorcy zostali bezpośrednio zaangażowani w procesy przedstawiania i interpretacji.

Naszkicowane powyżej przemiany, jakie obecnie zachodzą w muzeach, tworzą szereg nowych praktyk odbiorczych (Pater 2016), kulturowych potrzeb, zachowań i nawyków, a tym samym radykalnie przekształcają kontekst polonistycznej edukacji. Nie można go nie zauważać, a tym bardziej lekceważyć, bo wymusza on namysł nad funkcją i celami nauczania na lekcjach języka polskiego, a zwłaszcza nad sposobami poznawania przeszłości oraz kształtowania kulturowej czy zbiorowej pamięci ${ }^{7}$.

\section{LEKCJE DZIAŁANIA}

Przypomnę, że dawniej - co utrwalił w swej alegorii Ripa - siedzibą pamięci były uszy, bo do nich przekazywano słowa. Ślad tego przekonania można było znaleźć w karze, stosowanej niegdyś przez nauczycieli lub opiekunów, czyli w pociągnięciu za ucho właśnie, co miało służyć lepszemu zapamiętywaniu (por.

7 Tematowi temu był poświęcony drugi numer „Polonistyki” z 2011 roku (por. Niklewicz 2015: 165-173; o przemianach w kształceniu kulturowym i edukacji kulturowej w muzeum i szkole zob. Pilch i Rusek 2019). 
Kowalski 2007:569) ${ }^{8}$. Pomińmy ten anegdotyczny aspekt i skoncentrujmy się na pytaniu o model poznawania przeszłości, a zatem budowania pamięci kulturowej młodego pokolenia. W szkole zasadniczo oparty jest on na metodach podających.

Znając moc opowieści, nie zamierzam tego modelu kwestionować, wręcz odwrotnie - podkreślę, że nauczyciel może dla swych działań odnaleźć także daleki wzór w tradycji aojdów, z pojawiającymi się u nich stałymi formułami i systemem repetycji. Co więcej, idea muzeów narracyjnych i ich popularność uczy nas, że opowieść spajająca fragmenty wiedzy, pojedyncze dane, kulturowe ślady, angażująca emocję i wyobraźnię jest atrakcyjna poznawczo. Krzysztof Maliszewski (2015: 215-216), pisząc metaforycznie o nauczycielu jako wydarzeniu, powierzył mu zadanie tworzenia i dostarczania uczniom znaczących opowieści - znaczących, czyli istotnych dla kształtowania przez młodych rozumienia siebie i świata, a nie tylko cennych poznawczo. W polonistycznej praktyce podjęcie tego wyzwania będzie oznaczać tworzenie opowieści rzetelnej w wymiarze epistemicznym, niemającej jednak charakteru wykładu informacyjnego, ponieważ jego odbiór przypomina często poznawanie kolekcji obojętnej intelektualnie i emocjonalnie dla widza. Narracja nauczyciela powinna scalać różne, często rozproszone informacje oraz teksty, które wcześniej zaistniały na lekcjach lub mogły pojawić się w uczniowskim doświadczeniu, np. dzięki odbiorowi kultury popularnej. Pomagałaby zatem rozpoznawać przeszłość nie tylko w aspekcie faktograficznym, lecz także dzięki odwołaniu do wyobraźni i emocji czy też wykorzystaniu wcześniej zgromadzonych materiałów, a poza tym byłaby, może nawet przede wszystkim, otwarta na dopowiedzenia, polemiki i zapytania.

Zasadniczą nowość w sposobach poznawania tradycji niosą jednak podpowiedzi płynące z refleksji nad muzeum partycypacyjnym. Wyznaczają one inną rolę nauczycielowi, który - podobnie jak kurator wystawy lub kierownik projektu w muzeum partycypacyjnym - ma być twórcą koncepcji i organizatorem, co sprawia, że jego najważniejsze działania przeniesione są na czas przed zajęciami. Ich organizacja nie ogranicza się bowiem do przygotowań technicznych, choć i one - co muzealnikom uświadamia Nina Simon - są niezwykle istotne, lecz przede wszystkim polega na przemyślanym, bo wynikającym z wiedzy oraz doświadczenia (i programu) doborze zagadnień, utworów, różnego typu materiałów kontekstowych, które staną się punktem wyjścia do pracy uczniów. Sposób jej zainicjowania powinien być dokładnie zaprojektowany, ale jej wyniki nie są możliwe do przewidzenia, za to znane są jej zasadnicze cele. Działania uczniów

8 Autor przypomina także, że w średniowiecznych sądach istniał zwyczaj pociągania za ucho podsądnych podczas wygłaszania aktów prawnych, co miało sprawić, iż będą dobrze pamiętać szczególnie ważne fakty. 
powinny pozwolić im m.in.: odkrywać cenny, ale czasem bolesny kulturowy spadek; rozpoznawać zarówno interpretacyjną wspólnotę, jak i różnice w odbiorze tekstów kultury; dostrzegać różnorodność historycznych doświadczeń, a przede wszystkim umożliwić stawianie takich pytań o przeszłość, które wynikają z problemów, aporii, jakie młodzież spotyka w rozumieniu i doświadczaniu teraźniejszości. Dla utrzymania ciągłości kulturowej te pytania wydają mi się najważniejsze. Ich rolę podnosiła już dawno Margaret Mead (2000: 131-133). W rozprawie Kultura i tożsamość. Studium dystansu międzypokoleniowego z dużą mocą stwierdziła, że najważniejsze w edukacji są pytania młodych. Przeszłość jest dla nich obcym światem, dlatego mogą zadawać takie pytania, które starszemu pokoleniu w ogóle nie przyjdą do głowy, choć to ono jedynie może znać na nie odpowiedzi. Postulowane tutaj organizowanie sytuacji, w których uczniowie będą rozpoznawać obszary niepewności czy obcości, a przede wszystkim będą zadawać pytania, to odwrócenie schematu przedstawiającego biernych uczniów i dominującego nad nimi nauczyciela przekazującego wiedzę o przeszłości jak cenny spadek.

Przywołany w poprzednich częściach kontekst muzealny i dyskursów o pamięci może zatem w odniesieniu do kształcenia polonistycznego uruchamiać trzy rodzaje refleksji:

1. Skoro pamięć jest czymś żywym i jednocześnie konstruowanym, indywidualnym i kulturowym, to jej aktywizacja w szkole może lub powinna się odbywać analogicznie jak w muzeum, czyli poprzez doświadczanie, obcowanie ze zmysłowym konkretem lub dzięki nawiązywaniu do takiego doświadczenia przez opis, wreszcie przez łączenie własnych doznań uczniów z tym, co przedstawione w lekturach, w relacjach bliskich im osób. Lekcje nastawione byłyby wówczas na poszukiwanie odpowiedzi na pytania, jak przeżywano, jak postrzegano kiedyś jakiś problem, kwestię, rytuał czy zwyczaj, jak ich doświadczano, a jak my to robimy, co wynika $\mathrm{z}$ tej zmiany.

2. Skoro - o czym przekonują nowoczesne muzea - możliwość zaprojektowania własnej instalacji z dostarczonych elementów bardziej angażuje niż przechadzanie się pomiędzy przygotowanymi do biernego oglądania zbiorami, to warto zaproponować uczniom konstruowanie z lekturowych realiów różnych wizji minionego świata, którą mieli autorzy w danej epoce. Takie lekcje odpowiadałyby na pytanie, które doświadczenia z przeszłości wydają się uczniom ciekawe, ważne (może byłoby to np. życie uczniów w dawnych czasach, sytuacja zwierząt, sposoby komunikacji czy zwracania się do osób różnych stanów i w różnym wieku, relacje rodzinne), stawiałyby również przed młodzieżą zadania, by na podstawie 
zbiorów, dostępnych w internecie i w bibliotekach oraz muzeach, ukazać dany temat w formie np. filmiku, pokazu slajdów, odgrywanej scenki, kart do gry itp.

3. Skoro źródłem pamięci są także muzea, to wspólna w nich wizyta powinna stać się okazją do zadania pytań dotyczących ekspozycji i sposobów kształtowania pamięci, a zatem pytań o to, co i jak pokazano, a czego nie, jaka lub czyja perspektywa zdominowała całość. Mogłyby one stanowić punkt wyjścia do rozmowy o pamięci jako filtrze, a także o utworach jako jej mediach.

Na podstawie powyższych wniosków można zauważyć, że postulowane przemiany w polonistycznej edukacji dotyczą sposobów organizowania zajęć i ich formy zarówno w szkole, jak i poza nią (co wiąże się również z otwarciem na stałą, planową współpracę, np. z muzeami), a przede wszystkim wymagają pogłębionego namysłu nad treściami kształcenia, w tym nad dowartościowaniem kulturowego, antropologicznego trybu lektury, wreszcie związane są z umiejętnym organizowaniem pomocy dla nauczycieli, m.in. w zakresie potrzebnych materiałów czy wymiany doświadczeń. Stawka tych zmian jest wysoka. To ciągłość pamięci zbiorowej, ale też lepsze rozumienie siebie, swego czasu oraz swojego miejsca w cywilizacji i danej kulturze, przede wszystkim jednak to bardziej świadome i zniuansowane spojrzenie w przyszłość. Pamiętamy bowiem, że według jednej z alegorii Pamięć ma dwie twarze - jedną zwróconą ku przeszłości, a drugą ku czasom, które dopiero mają nadejść.

\section{BIBLIOGRAFIA}

Assmann, A. (2009). Przestrzenie pamięci. Formy i przemiany pamięci kulturowej. W: M. Saryusz-Wolska (red.), Pamięć zbiorowa i kulturowa. Wspótczesna perspektywa niemiecka (s. 101-142). Kraków: TAiWPN Universitas.

Assmann, J. (2015). Pamięć kulturowa. Pismo, zapamiętywanie i polityczna tożsamość w cywilizacjach starożytnych. Warszawa: Wydawnictwa Uniwersytetu Warszawskiego.

Bartol, K. (2016). Mnemosyne w mitycznej i społecznej przestrzeni Grecji starożytnej. W: M. Cieśla-Korytowska, J. Czernik (red.), Mnemosyne. Pamięć jako źródto dzieta sztuki (s. 11-22). Kraków: Avalon.

Borusewicz, M. (2012). Nauka czy rozrywka. Nowa muzeologia w europejskich definicjach muzeum. Kraków: TAiWPN Universitas.

Czarnowski, S. (1956). Dawność a teraźniejszość w kulturze. W: tegoż, Studia z historii kultury (s. 108-121). Warszawa: PWN.

Halbwachs, M. (2008). Społeczne ramy pamięci. Warszawa: PWN.

Heesen, A. te (2016). Teorie muzeum. Warszawa: Niemiecki Instytut Historyczny, Wydawnictwo Neriton. 
Huyssen, A. (1995). Twilight Memories: Marking Time in a Culture of Amnesia. London: Psychology Press.

Irvine, L. (2006). In memoriam Duncan Ferguson Cameron 1930-2006. Pobrane z: www.maltwood.uvic.ca/cam/archived_news/20060429_memoriam_cameron.html [dostęp: 10.01.2020].

„Jak to widzisz?” - wystawa w Muzeum Pałac Herbsta. (2018). Pobrane z: https://uml. lodz.pl/kalendarz-wydarzen/wydarzenie/jak-to-widzisz-wystawa-w-muzeum-palac-herbsta-id24101/2018/12/12 [dostęp: 26.09.2019].

Janus, A. (2015). Muzea i ludzie. W: A. Banaś, A. Janus (red.), Laboratorium muzeum. Społeczność (s. 9-19) Warszawa: Muzeum Warszawy.

Karczewski, L. (2015). Konstruowanie edukacji. Uwagi po szkoleniu Edukacja w muzeum sztuki współczesnej. W: ABC edukacji w muzeum. Muzea sztuki wspótczesnej, rezydencjalne, wielooddziałowe i interdyscyplinarne (s. 24-35). Pobrane z: https:// nimoz.pl/files/publications/23/ABC_Edukacji_w_muzeum.pdf [dostęp: 26.07.2020].

Korzeniewski, B. (2006). Muzealizacja - ku czy przeciw przeszłości. W: M. Popczyk (red.), Muzeum sztuki. Od Luwru do Bilbao (s. 221-227). Katowice: Muzeum Śląskie. Kowal, P., Wolska-Pabian, K. (red.). (2019). Muzeum i zmiana. Losy muzeów narracyjnych. Warszawa-Kraków: Muzeum Powstania Warszawskiego, TAiWPN Universitas.

Kowalski, P. (2007). Kultura magiczna. Omen, przesqd, znaczenie. Warszawa: Wydawnictwo Naukowe PWN.

Maliszewski, K. (2015). Dotknięcie pedagogiczne - nauczyciel jako „wydarzenie”. W: tegoż, Pedagogika na pograniczu światów. Eseje z cyklu „Medium Mundi”(s. 109-120). Katowice: Uniwersytet Śląski.

Mead, M. (2000). Kultura i tożsamość. Studium dystansu międzypokoleniowego. Warszawa: Wydawnictwo Naukowe PWN.

Niklewicz, B. (2015). Język muzeum, czyli o nowych sposobach odczytywania wystaw. Polonistyka. Innowacje, nr 2, 165-174. https://doi.org/10.14746/pi.2015.1.2.12

Pater, R. (2016). Edukacja muzealna - muzea dla dzieci i młodzieży. Kraków: Wydawnictwo Uniwersytetu Jagiellońskiego.

Pilch, A., Rusek, M. (2019). Wspótczesny museion. Edukacja kulturowa z perspektywy uniwersytetu, muzeum, szkoły. Kraków: Wydawnictwo Uniwersytetu Jagiellońskiego.

Piotrowski, P. (2011). Muzeum krytyczne. Poznań: Dom Wydawniczy Rebis.

Radecki, G. (2015). Obszar wydzielony czy nowe otwarcie? Edukacja muzealna jako muzeologia. W: ABC edukacji w muzeum. Muzea sztuki współczesnej, rezydencjalne, wielooddziałowe i interdyscyplinarne (s. 6-23). Pobrane z: https://nimoz.pl/files/ publications/23/ABC_Edukacji_w_muzeum.pdf [dostęp: 26.07.2020].

Ripa, C. (2012). Ikonologia. Kraków: TAiWPN Universitas.

Rybowska, J. (przeł.). (2011). Hymn orficki 77, Do Mnemosyne. Nowy Filomata, t. 15(1), 28.

Saryusz-Wolska, M., (2014a). Memory boom. W: M. Saryusz-Wolska, R. Traba (red.), Modi memorandi. Leksykon kultury pamięci (s. 224-225). Warszawa: Wydawnictwo Naukowe Scholar.

Saryusz-Wolska, M. (2014b). Pamięć magazynująca. W: M. Saryusz-Wolska, R. Traba (red.), Modi memorandi. Leksykon kultury pamięci (s. 341). Warszawa: Wydawnictwo Naukowe Scholar. 
Saryusz-Wolska, M., Traba, R. (red.). (2014). Modi memorandi. Leksykon kultury pamięci. Warszawa: Wydawnictwo Naukowe Scholar.

Simon, N. (2015). Muzeum partycypacyjne. W: A. Banaś, A. Janus (red.), Laboratorium muzeum. Społeczność (s. 22-38). Warszawa: Muzeum Warszawy.

Sokolnicka, K. (2012). Alegoria pamięci. Pobrane z: https://zasoby.msl.org.pl/arts/ view/5704 [dostęp: 23.09.2019].

Szymborska, W. (1996). Widok z ziarnkiem piasku. 102 wiersze. Poznań: Wydawnictwo a5.

Valéry, P. (1974). Problem muzeów. W: tegoż, Rzeczy przemilczane (z pism o sztuce) (s. 146-149). Warszawa: PIW.

Widok zza bliska. Inne obrazy Zagłady. (2018). Pobrane z: https://etnomuzeum.eu/ wystawy-czasowe/widok-zza-bliska-inne-obrazy-zaglady [dostęp: 26.09.2019].

Wystawa „Jak to widzisz?”. (2018). Pobrane z: http://palac-herbsta.org.pl/wydarzenie357-wystawa_jak_to_widzisz.html [dostęp: 26.09.2019].

Ziębińska-Witek, A. (2014). Zwrot performatywny w muzeach - między teorią a praktyką. Teksty Drugie, nr 1, 293-308.

Żybert, E. (oprac.). (2012). Hymny orfickie. Wrocław: Oficyna Wydawnicza Atut. 